\title{
PROFESSIONELE BENADERINGE TOT DIE VERSORGING VAN DIE BEJAARDE
}

\author{
W.J. KOTZÉ \\ Professor en Hoof, Departement Verpleegkunde \\ Universiteit van Pretoria
}

\section{OPSOMMING}

There are few phenomena in the life of man which cause so many misconceptions and fallacies as the concept of aging. Probably the reason for this is to be found in the materialistic spirit of our times to which man is constantly exposed from the embryonic phase of his existence.

Unless the members of the therapeutic team themselves believe in the meaning of life and in the unique, irreplaceable value of each human life, and, unless this belief is realised in their own personal lives and in relation to others, they will not be able to lead any other person to a meaningful life.

D AAR is min verskynsels in die lewe van die mens waaroor daar meer dwalinge en wanbegrip bestaan as oor die oudword. Waarskynlik is die gronde hiervoor geleë in die materialistiese tydsgees waaraan die mens vandag reeds vanaf die embrionale fase van sy bestaan blootgestel is.

Die biologiese verouderingsproses is 'n werklikheid. Die gevaarlikste veranderinge wat daaruit voortvloei is die wat die mens se weerstand teen 'n verskeidenheid siektes en sy vermoë om van siekte en terugslae te herstel aftakel - daardie faktore wat sterwe gedurende die vyf en sewentigste lewensjaar ongeveer een en veertig maal 'n groter moontlikheid as gedurende die twintigste lewensjaar maak"). Met die hulp van die moderne geneeskunde mag die mens 'n gevorderde leeftyd bereik - 'n moontlikheid wat met die hulp van die eksperimentele gerontologie in die toekoms waarskynlik sal toeneem.

Of hierdie vooruitsig vir die mens genade of onreg inhou, is 'n ope vraag. Is een van die teenstrydighede wat die tyd waarin ons leef kenmerk nie juis geleë in die groeiende belofte van 'n hoër lewensverwagting met daarteenoor die verskynsel dat die gemeenskap opmerklik traag voorkom om aan sy groeiende getal bejaardes die geleentheid tot ware selfstandige en sinvolle bestaan te gun nie? Dit word van die mens verwag om die bereiking van 'n spesifieke chronologiese ouderdom uit te tree en die rol van bejaardwees te aanvaar en dit volgens die verwagtinge van die gemeenskap te vertolk tot sy sterfdag - 'n soort van 'bestaan op afstand' vanaf 'n deur-die-gemeenskap-voorgeskrewe datum in sy lewe, volgens gemeenskapsvoorskrifte, te begin voer. Alex Comfort in sy werk 'A good age' verwys hierna as 'Sociogenic aging' _ 'n bejaardheid aan 'n persoon opgelê deur die gemeenskap, wat van die gevorderde leeftyd 'n pynlike ervaring kan maak:

"This means, quite simply, the role which society imposes on people when they reach a certain chronologic age. At this age they 'retire', or in plain words, are rendered unemployed, useless and, in some cases, impoverished. After that transition, and in proportion to their chronological age, they are prescribed to be unintelligent, unemployable, crazy and asexual.

Prescription is a nasty and familiar process. It commonly involves two principles - the unpeople principle and the expendable people principle."2).

Volgens Comfort dui moderne navorsing daarop dat 'n groot mate van die geestes- en gesindheidsveranderinge wat by bejaardes waargeneem word nie die biologiese effekte van veroudering is nie, maar die gevolge van rolvertolking - na 'n sekere ouderdom is die mens veronderstel om fisies en intellektueel onseker te word - terwyl veroudering inderwaarheid geen radikale verandering inhou nie en positief, opbouend benader behoort te word.

Dié teenstrydigheid in die moderne beskouing van bejaardheid verteenwoordig maar 'n enkele van die vele voorbeelde vandag van die ongelyke wedloop tussen mens en wetenskap.

Ons staan voor die werklikheid van 'n voortskrydende, tempoversnellende, bloeiende wetenskap. Hierdie werklikheid maak voortdurende besinning oor gesindhede en denke oor plekinruiming vir die mens van alle lewensfases in die moderne tegnokratiese gemeenskap 'n daaglikse noodsaaklikheid. Daar moet egter gewaak word teen veralgemenings om die ingewikkeldhede van die moderne gemeenskap te vereenvoudig. 
Dit waarteen Comfort beswaar maak spruit voort uit heersende veralgemenings wat bestaan in die benaderinge tot die bejaarde. Die bejaarde mag nie uit beginsel as probleem benader word nie en àlle persone bo 'n gegewe ouderdom kan nie as bejaard gekategoriseer word nie. Die vertrekpunt moet steeds die individu vanuit 'n eie leefwêreld en met besondere eie node wees.

Terwille van die inwerkingstelling van die proses van dienslewering, d.i. die bepaling van die behoeftes aan fasiliteite vir die versorging van bejaarde persone, die bepaling van beleid, die beplanning, daarstelling en instandhouding van dienste, en die voortdurende evaluering van elk van hierdie fasette met die kwaliteit van dienslewering as hoofsaaklike maatstaf, is dit weliswaar onvermydelik dat daar van bepaalde norme, soos ouderdomsindeling gebruik gemaak sal word. Vir hierdie doeleindes is die gebruikmaking van verantwoordbare veralgemenings geregverdigd. Daar word hier spesifiek verwys na daardie veralgemenings wat voortspruit uit wetenskaplike navorsing soos verwerklik in die epidemiologie. Die epidemioloog se bydrae tot die verskillende fasette van die administratiewe proses in moderne gesondheidsdienslewering word immers vandag erken as van onmisbare belang.

Die vertrekpunt in die besinning oor professionele benaderinge tot die versorging van die bejaarde moet dus dié van verantwoordbaarheid wees - die beskikbaarstelling en instandhouding van 'n diens, wat met sy toereikendheid, doelgerigtheid en effektiwiteit getuig van die begrip en insig van die gesondheidspan op beleidsbepalende en direkte diensleweringsvlak met betrekking tot die totale nood en verwagtinge van die bejaarde persoon.

Verantwoordbaarheid in die oorweging van dienslewering aan die mens, ook in die gesondheidsdienste, vereis die verwerkliking van beide instrumentele en ekspressiewe doelstellings ${ }^{3)}$ :

* instrumentele doelstellings, as dié gerig op die daarstelling van 'n verwysingsraam en 'n toereikende, fisiesveilige milieu waarbinne effektiewe dienslewering sal kan plaasvind. Dit behels die doelstellings van die totale administratiewe proses op alle vlakke van die hiërargiese leer. Die effektiwiteit daarvan blyk op diensleweringsvlak waar dit in die terapeutiese situasie verwerklik word;

* ekspressiewe doelstellings is gerig op -

- die daarstelling van 'n omgewing wat bevorderlik vir alle terapeutiese gebeure, die funksionering van die terapeutiese span en die verhouding tussen die individuele spanlede en die pasiënt en sy naasbestaandes sal wees;

- die verpersoonliking en vertolking van alle dienste aan die pasiënt sodat dit vir hom en sy naasbestaandes betekenisvol en aanvaarbaar - 'n positiewe ervaring sal word; en

- die begeleiding van die pasiënt tot selfstandige besluitneming, handeling en verantwoordbare sinvolle bestaan.

Vanuit hierdie beginsel as vertrekpunt is dit duidelik dat die versorging van die bejaarde vanuit die oogpunt van verwerkliking van instrumentele en ekspressiewe doelstellings aan die eise van wetenskaplike verantwoordbaarheid moet voldoen.

Die bejaarde self, die veranderinge waarmee hy persoonlik gekonfronteer word, moet die hoofsaaklike bron vir riglyne word wanneer daar aanvullend tot die epidemiologiese bevindinge na benaderinge gesoek word. Met die oog op die bepaling van die aard en omvang van bejaardesorgdienste behoort die epidemioloog ook in die volgende verband gegewens in te win:

* fisiese en geestesgesteldheid met die oog op verkryging van ' $n$ profiel van die afhanklikheids/selfstandigheidstand van bejaarde persone in die gemeenskap;

* omgewingsfasiliteite met die oog op beraming van die beskikbaarheid en aard van behuising, lewensmiddele, hulp/ondersteunende dienste en ander fasiliteite in die tuisomgewings van bejaardes.

Die National Health Service Operational Research Group van die Royal Institute of Public Administration in Brittanje wys daarop dat 'n klassifikasiesisteem, gebaseer op bejaarde persone se afhanklikheid van versorging, met behulp van opnames, die inligting beskikbaar in pasiëntrekords en die ontwikkeling van bevolkingsprofiele hiervolgens, konstrueer kan word ${ }^{4}$.

Die ontwikkeling van betroubare instrumente waarin die behoeftes van die individu die primêre oorweging is, soos dié van die NHSORG*, tesame met die statistiese gegewens verkrygbaar uit bevolkings- en lewenstatistieke, bied 'n verantwoordbare grondslag waaruit die formulering van instrumentele doelstellings in die voorsiening van fasiliteite vir bejaardesorg en dienslewering aan die bejaarde individu kan voortvloei.

Wanneer die aard van diensleweringsfasiliteite by verwysing en die benadering tot die bejaarde persoon binne die diensleweringsituasie oorweeg word, is soos gesê, die individu self, sy besondere omstandighede, die besondere van die aandag wat hy benodig, die enigste verantwoordbare vertrekpunt. Die mens se kosbaarste besitting is sy persoonlikheid. Die riglyne wat die referent dus uiteindelik in die verband sal voorhou is dié gemik op die preservering van die persoonlikheid - en waarin die beginsels van die bevordering van onafhanklikheid en geborgenheid sleutelbegrippe sal wees.

Dit is met hierdie oerwaarheid in gedagte dat T.N. Rudd skryf.

"Personality, in every stage of life, is the individual's most treasured possession and happiness in old age may well depend on the degree to which personality is retained, and its needs met" en hy Goethe aanhaal

"Folk and serf and conqueror

These concede in every age:

The sons of earth find greatest joy

In personality alone",6).

\section{VERANDERINGE WAT BEJAARDHEID TIPEER}

Namate die lewensjare vorder en die mens verander, verander sy plek en bydrae in die samelewing, asook sy belewinge daarvan. Om enigsins tot begryping van die bejaarde te kom is dit nodig om die veranderinge wat die bejaardheid of laatvolwassenheid ${ }^{7)}$ tipeer kortliks te verken.

*National Health Service Operational Research Group 
Verandering van fisiese moontlikhede ${ }^{\text {g) }}$.

'n Volledige bespreking van die fisiese veranderinge van hierdie lewensfase binne die bestek van hierdie referaat sou ontoepaslik wees. Daar word dus volstaan met enkele waarnemings wat van besondere belang in die versorging van die bejaarde is en nie altyd genoegsame aandag kry nie.

Die motoriek van die mens in sy gevorderde lewensfase verander langsamerhand in die sin dat oortollige beweginge wat aan die handelinge van jonger persone natuurlikheid en uitdrukkingskarakter gee, verdwyn.

Hierdie bewegingsarmoede by die bejaarde is hoofsaaklik die gevolg van somatiese veranderinge wat in gevorderde leeftyd in die senuweestelsel plaasvind. Die uitgesproke teenwoordigheid daarvan word duidelik in patologiese afwykings waarvan Parkinsonisme 'n bekende voorbeeld is".

Veranderinge van verdere besondere belang is die afname in sensoriese en persepsuele funksioneringe soos wat dit sig voordoen in die gesigsvermoë, die gehoorvermoë en die liggaamlike persepsievermoë - d.i. ten opsigte van ruimtelike oriëntering van die liggaam, gevoeligheid vir pyn, kinestesie (bewegingsin), die sin vir ewewig en die vermoë om by fluktueringe in temperatuur aan te pas.

Afgesien van die ooglopende oorweging wat voornoemde fisiese verskynsels in die versorgingsgebeure verdien moet dit hier beklemtoon word dat afname in die gesigs- en gehoorvermoë uitermate bydra tot die belewing van afgesonderdheid en eensaamheid by bejaarde, asook tot 'n oorweldigende gevoel van onmag en neerslagtigheid, omdat dit hom afhanklik van ander maak, en onveiligheid, vanweë die onderbreking van die kontak met die werklikheid wat dit verteenwoordig. Verlies van gesig en gehoor maak van sy belewing van homself as ongeborge en bedreigd 'n konkrete werklikheid.

Die verlies van vrye beweeglikheid en die bewuswording van afname in sy fisiese en psigies-geestelike moontlikhede, is vir die bejaarde vanweë die implikasies wat dit vir hom as selfbeslissende mens inhou 'n pynlike werklikheid wat immer deur die lede van die terapeutiese span verstaan en in gedagte gehou moet word ${ }^{10)}$.

\section{Veranderinge in die leefwêreld ${ }^{11}$.}

"Daar breek 'n dag aan waarop ons die tuig moet neerlê, die juk moet afgooi, moet uitspan ... die kantoordeur moet toegetrek en die sleutels aan 'n ander oorhandig word"' (Oberholzer) ${ }^{12)}$.

Die aftrede verteenwoordig sekerlik die mees ingrypende verandering in die laatvolwassenheid. By die man gaan dit hoofsaaklik om die verlating van die beroepsarbeid - by die vrou tot 'n mindere mate ook. By haar is daar egter 'n ander veel meer ingrypende verandering in die sin van die totale oorbodigwording van haar wanneer haar lewenstaak van kinderversorging en -opvoeding tot 'n einde kom. As beroeps-arbeid èn die taak van moederwees tot so 'n mate die inhoud van die lewe geword het dat die oudag letterlik met leë hande ingegaan word, verteenwoordig die aftrede in die lewe van so 'n man of vrou 'n krisistyd ${ }^{13)}{ }^{14)}$. Die aftrede beteken in dié geval die verlies van die hoofbron van selfvervulling en toebehorenheid en van identiteit en status. C.J.H. Venter wys daarop dat die selfbeeld geskaad en die gevoel van eiwaarde hierdeur ondermyn word ${ }^{15)}$.

Ander faktore wat bydra tot moeilike aanvaarding van die aftrede is:

- eerstens, die klem wat in die hedendaagse kultuur op jeugdigheid, spoed, krag, doeltreffendheid en produktiwiteit geplaas word en die eensydige identifisering van verhewe en estetiese waardes met die jeug - die sogenaamde jeuggerigtheid van die twintigste eeu. Hierdie verskynsel lei tot bevooroordeelheid teen die ouderdom en die bejaarde - vooroordeel wat weliswaar die afskynsel van die vrees van die moderne jeug vir die ouderdom mag wees;

- tweedens, die neiging vandag om bekwaamheid aan doeltreffendheid en funksionaliteit te meet en die waarde wat aan die samehang tussen status en waardigheid en die aard en prestasie van beroepswerk geheg word. Wanneer die funksionaliteit dus afneem soos in die laatvolwassenheid neem ook die aansien van die persoon af - wat in vele gevalle die aansporing is vir aktiewe deelname en produktiwiteit en die voortsetting van beroepsarbeid, soms in 'n ander sfeer, na die amptelike aftrede. Venter wys daarop dat veroudering vinniger plaasvind in 'n gemeenskap waar bejaardes bloot op grond van hul ouderdom geëer word en waar hul ouderdom hul aansien bepaal $\left.^{16)}{ }^{17}\right)^{18)}$;

- derdens, sosio-ekonomiese oorwegings waar daar onvoldoende, selfs geen voorsiening vir die oudag gemaak is nie.

Vanweë die verskynsel van toenemende verstedeliking in geîndustrialiseerde maatskappye en die gepaardgaande verandering van die gesinstruktuur tot die van die nukleêre gesin, het die plek van die bejaarde verander van familiehoof na die van 'n bykomende gesinslid, as onderhorige. Juis hierdie tendens lei tot die institusionalisering van vele bejaardes in tehuise. In Suid-Afrika bevind ongeveer agt persent van blanke bejaardes hulle vandag tuis in tehuise vir bejaardes ${ }^{19}$. A.M. Rose en W.A. Peterson wys daarop dat die inwoning van 'n bejaarde by 'n getroude kind gewoonlik lei tot 'n mate van verlies van die selfbeeld as gevolg van degradering van die rol van so 'n persoon tot die van afhanklikheid en onderhorigheid ${ }^{20)}$. Die verstedelikingsen massafiseringsverskynsel van die geîndustrialiseerde gemeenskap lei in baie gevalle tot toenemende sosiale afsondering, gebrek aan beroepsgeleenthede en verlies van die aansien van die bejaarde sodat:

"Hy voel dat hy sy nuttigheidsvlak - ook vir ander - verbygesteek het: Hy kan geen nuwe rol en identiteit in die minderheidsgroep (bejaardes) waaraan hy nou behoort, vind nie"21).

Omdat baie bejaardes passief ingestel is volg vervreemding van die res van die gemeenskap met gevoelens van minderwaardigheid, eensaamheid, 
waardeloosheid en aggressie ${ }^{22)}$. In die praktyk van die volksgesondheidsverpleegkundige word vele bejaardes só aangetref in swak behuisingstoestande, vereensaamd en alleen agtergelaat deur naasbestaandes, en dikwels in uiterste verwaarlosing - toestande wat dikwels nie die gevolg van net swak sosio-ekonomiese moontlikhede is nie.

\section{Veranderde belewinge en singewing ${ }^{23)}$}

C.K. Oberholzer beklemtoon dat dit hoofsaaklik afhang van die soort mens wat die bejaarde is wat sal bepaal met welke gesindheid die oudag tegemoet getree word:

"Die oudag, net soos enigeen van die ander modi, is nie iets nie, maar wel die geleentheid tot iets, naamlik om die lotgevalle van die oudag mooi te hou. Die opvallendste by so baie bejaardes is die spontane dankbaarheid oor 'n lang pad wat agter die rug lê, daarby 'n pad waaroor hy hom nie hoef te skaam nie" 24).

P.A.M. Eliëns in sy onderskrywing van die beskouing van $\mathrm{D}$. Wechsler beklemtoon dat die verstandelike vermoëns van die mens tot laat in die lewe onaangetas bly deur ongunstige inwerking van gevorderde leeftyd ${ }^{25)}$. Hy kom tot die gevolgtrekking dat die mens tot gevorderde leeftyd nog in staat tot aansienlike bydraes is omdat hy nie net sy greep op die belangrikste van sy psigiese en intellektuele funksies behou nie, maar sy meesterskap daarvan selfs kan vergroot ${ }^{26)}$.

Selfs al sou die bejaarde van die wesenlike aspekte van sy persoonlikheid moet prysgee, sê Eliëns, sodat hy aan sy menslike vryheid, selfbeskikking en skeppingskrag moet inboet, het hy as opgaaf om die innerlike akt van aanvaarding en berusting tot stand te bring. Hiermee verwerklik hy selfs by sy sterwe die hoogste moontlikheid van menswees, naamlik die oorgawe van homself aan $\operatorname{God}^{27)}$.

H.C. Rüke, in sy vergelyking van die bejaardheid met die naseisoen by ' $n$ vakansie-oord, wys daarop dat die bejaarde ten spyte van die geleenthede wat nou vir hom geslote is, die goeie dae moet uitsoek. Aanvaarding van sy beperkinge gee aan die bejaarde 'n ongekende gevoel van vrede wat die mens in die volle seisoen nie ken nie. Plotseling ontstaan daar nuwe belangstellinge. Die beperkinge ten spyt bestaan daar nuwe moontlikhede ${ }^{28)}$.

$\mathrm{Na}$ aanleiding van die 'disengagement'-teorie van Buytendijk huldig J.M.A. Munnichs die mening dat wanneer die bejaarde distansie geskep het, hom losgemaak het van sy vroeëre wêrldbetrokkenheid, hy vanuit hierdie afstand weer belangstelling kry - hoewel nou anders - vir die gewone lewe en die wêreld. Sy betrokkenheid is die van hernude 'engagement' op afstand ${ }^{29)}$.

In sy navorsing oor faktore wat 'n bepalende invloed op die belewinge van die bejaarde kan hê, bepaal C.J.H.
Venter hom tot drie aspekte, naamlik, sterwensproblematiek, vrees vir die dood en instelling op die eindigheid van die bestaan. Hy kom tot die gevolgtrekking dat bejaardes nie gepreokkupeerd is met doodsgedagtes en -vrees nie en dat gelowige bejaardes op 'n meer positiewe wyse aan die dood dink - dat daar nie preokkupasie is nie, maar aanvaarding. Bejaardes vrees wel die dood. Dit is menslik. Hierdie vrees spruit nie soseer uit godsdienstige oorwegings nie, maar veel eerder uit dit wat met die dood in verband staan, naamlik, pyn, siekte, lyding, vrees om alleen gelaat te word en besorgdheid oor dié wat agterbly ${ }^{30}$. Met betrekking tot die belewing van sy bestaan as eindig verwys Venter na die beskouing van Munnichs. Die hoofmomente wat uit hierdie beskouing na vore tree is:

* wanneer die bejaarde sy eie beperktheid en eindigheid erken, word 'n nuwe betrokkenheid op die lewe moontlik. Bejaardes wat nie tot aanvaarding hiervan kom nie 'hang' die lewe sinloos aan terwyl hierdie lewe hom in toenemende mate ontwyk, wat tot angs en onsekerheid lei;

* die bejaarde kan die eindigheid van sy bestaan slegs aanvaar as hy ' $n$ bepaalde sin daaraan gee. Ontkenning van die eindigheid en dood laat in ' $n$ sin ook die sin en betekenis van die aardse lewe verdwyn omdat dit juis die eindigheid van die mens se aardse lewe is wat hom die beperkings daarvan leer ken en aanvaar;

* aanvaarding van die eindigheid hang ten nouste saam met lewens- en wêreldbeskouing, persoonlikheid en temperament;

* hoewel aanvaarding van die eindigheid 'n opgawe vir elke mens is, is daar tog 'n sterker bewuswording daarvan in die latere lewensjare.

Venter kom tot die slotsom dat die wyse van eindigheidsaanvaarding en verwerking beslissende betekenis het vir die wyse waarop die ouderdom beleef word ${ }^{31)}$.

Verkenning van die veranderinge in die lewe van die persoon in die laatvolwassenheid maak 'n mens bewus van die werklikheid dat die bejaarde nood het aan oneindig veel meer as fisiese versorging. Om dit vir hom makliker te maak om tot die einde van sy bestaan sinverrykend te leef, die laaste barrikade oor te steek as waardige mens, moet ook die leweraars van gesondheidsdienste verseker dat hul benaderinge tot die bejaarde persoon gerig is op die totaliteit van sy behoeftes, d.i fisies-psigies-geestelik.

Die eerste en belangrikste beginsel in die benadering tot die bejaarde is dat hy nie uit sy vertroude, veilige tuisomgewing weggeneem of aan bedrus onderwerp moet word tensy dit noodsaaklik is nie. 
Die ander belangrike beginsels wat tegelyk ook as doelstellings van die terapeutiese bemoeienis kan dien is die volgende:

* die herstel van sy onafhanklikheid en dat in die analisering van die aard van die sieke se afhanklikheid, ten einde tot beplanning vir optrede te kom, elke aspek afsonderlik en in verhouding tot sy daaglikse lewenswyse oorweeg moet word. Dit is van oneindig groot belang dat alle pogings daarop gerig sal wees om die sieke tot menswaardige, as sinvolle bestaan, te begelei. Dit gaan in die beplanning van terapie daarom dat dit gerig word op die ontplooiing van oorblywende moontlikhede en op die oplos van probleme, soos byvoorbeeld die wat ontstaan vanweë fisiese remminge wat in die daaglikse bestaan die bejaarde se lewe ondraaglik kan maak. Dit mag faktore of remminge wees wat nie noodwendig betrokke by, of die rede vir hospitalisasie was nie. Die gerigtheid van die terapeutiese span moet altyd op die totaal van die sieke se hulpbehoewendheid wees en nie net op 'n siek orgaan of liggaamsdeel nie;

* die skep van 'n omgewing wat gunstig is vir psigiesgeestelike gedying;

* die bevordering van terapeutiese spanwerk waarin die geneeskundige, verpleegkundige, pasiënt, gesin (waar van toepassing) en ander terapeute in samespreking met en raadpleging van mekaar saamwerk in die beplanning en verwerkliking van doelstellings. Rudd wys daarop dat die verpleegkundige in die totaal van die gebeure 'n sleutelrol vertolk, veral met betrekking tot konstante hulpverlening en steungewing en koördinering van terapie. Hy dring daarop aan dat die sieke self die finale woord het, dat alle bedrywighede vir hom verstaanbaar en duidelik sal wees, sy voorkeure volle oorweging sal geniet en dat alle beplanning volgens hierdie voorkeure en met sy instemming sal geskied. Dit geld nie net beplanning vir die gebeure tydens sy hospitaalverblyf nie, maar ook en veral dié wat insake sy toekoms na sy ontslag gedoen word ${ }^{32}$.

* wanneer nodig dus, beplanning van die siek bejaarde se heenkome na ontslag uit die hospitaal. Indien dit nodig blyk dat herbeplanning van sy tuisomgewing, sy lewensomstandighede, en so meer, gedoen sal word, moet dit vroegtydig 'n aanvang neem om te verseker dat hy veilig, goed versorgd en sover enigsins moontlik, selfstandig sy lewe sou kon voortsit sonder om sy menswaardigheid in te boet ${ }^{33)}$.

Die sukses van terapeutiese beplanning en die terapeutiese gebeure self is tot 'n hoë mate afhanklik van die gehalte van verhoudingstrukture wat tussen die pasiënt en die lede van die terapeutiese span verwerklik word. Dit is hieruit dat geborgenheidsbelewing en die bereidheid om betrokke te raak by sy eie terapie, en indien die moontlikheid daarvoor bestaan sy eie versorging of dele daarvan uiteindelik selfstandig waar te neem, voortvloei.
DIE VERWERKLIKING VAN GEBORGENHEIDSBELEWING

'n Aspek van besondere belang wat so dikwels vergete bly by die opname van 'n sieke, ook by die bejaarde, is die vermindering van besorgdheid met betrekking tot dit wat hy tuis agtergelaat het - 'n eggenote, 'n troeteldier, 'n kleinkind van werkende kinders wat bedags van sy versorging afhanklik was, en so meer. Deur die nodige inligting in te win in hierdie verband en selfs maatreëls te tref vir die versorging van so 'n agtergeblewene kan die sieke gerus gestel word.

Dit is belangrik dat die samewerking van die bejaarde se naasbestaandes verkry word om hom gereeld te besoek, die versorging van sy nagklere en die voorsiening van klein persoonlike noodsaaklikhede waar te neem en na sy belange om te sien. Die belang van eerlikheid in hul omsien na sy sake moet beklemtoon word. Veranderde reèlings insake sy verblyfplek, sy besittings moet met sy wete en toestemming gedoen word. By 'n bejaarde wat voel dat hy deur sy dierbares versaak en bedrieg word, ontstaan die belewing dat hy niemand kan vertrou nie, selfs nie eens diegene wat die naaste aan hom verwant is nie. Afgesien van die vertroue wat hom ontneem word, versterk sulke gebeure, al wat dit hoe goed bedoel, sy gevoel van ontredding en eensaamheid en maak van die oorgang van vertroude wêreld, veiligheid, na die van vreemcheid en onveiligheid 'n oorweldigende werklikheid.

\section{VERWERKLIKING VAN VERHOUDING- STRUKTURE AS VOORWAARDE VIR GEBORGENHEIDSBELEWING}

\section{Die begrypingsverhouding}

Daar is by die bejaarde sieke die intense verlange dat hy as mens, en in sy nood en sy belewinge van homself as anders en onveilig raakgesien, verstaan en aanvaar sal word. Daar moet begryp word dat die bejaarde die eindigheid van sy bestaan baie werklik in sy siekwees beleef. As mens vrees hy die inhoude van siekwees van pyn, ongemak en lyding en die eise wat daar aan hom gestel gaan word. Hy voel besorgd oor diegene wat hy, sou hy sterf, moes agterlaat. Selfbejammering, oorafhanklikheid, oënskynlik onredelike veeleisendheid en aggressie en oormatige terugtrekking is veel eerder uitinge van ongeborgenheid as van enigiets anders.

Die sogenaamde disoriëntering wat kort na opname in die hospitaal by sovele bejaardes waargeneem word, is blyke van die oorweldiging van die sieke deur die onverwagte vreemdheid en onbekendheid van hierdie nuwe wêreld en gebeure wat daartoe lei dat hy homself as uiters onveilig beleef. Daar kan inderdaad veel gedoen word om die bejaarde die geleentheid te bied om sy greep op homself en die wêreld te herwin. Faktore wat bydra tot die ontstaan van hierdie verwardheid as verlies van sy greep op die werklikheid is:

* die ontneming van alle persoonlike besittings sodat 
daar niks oorbly om hom aan sy vertroude leefwêreld te herinner nie;

* die toediening van sedeermiddels. Die bejaarde het tyd nodig om gewoond te raak aan 'n veranderde omgewing. Onder invloed van sedeermiddels word hierdie geleentheid hom ontneem en dra inderdaad by tot die skep en verergering van verwardheid;

* die onoordeelkundige aanwending van bedtralies vanweë die wanopvatting dat hy só veiliger sal wees ${ }^{34)}$,

* die onbekendheid van die omgewing, van die uitleg van die saal, met gevaar van verdwaal, verlies van ewewig en val, onkunde met gebruik van kommunikasiesisteem sodat hy nie hulp kan ontbied nie, en so meer;

* gebeure in en om sy behandeling wat sonder waarskuwing of verduideliking vooraf plaasvind, selfs afgehandel is, voordat hy die tyd vind om dit te interpreteer en betekenis daaraan te gee;

* onverstaanbare geluide en haastige bewegings van bedrywighede in sy onmiddellike omgewing;

* die beweging vanuit 'n helderverligte vertrek na 'n donker of swakbeligte gang of vertrek;

* die afwesigheid van die bekende gesigte van sy naasbestaandes, sonder die oortuiging en gerusstelling dat hulle weer terugkom, sodat hy voel asof hy alleen en uitgelewerd aan die vyandigheid van vreemde, onbereikbare mense en 'n onbekende wêreld agtergelaat is.

Al hierdie is vermybare faktore wat met die regte beleid en beplanning van dienste aan die bejaarde glad nie hoef te bestaan nie.

Die stel van realistiese eise aan die bejaarde is vir hom 'n aanduiding dat hy aanvaar en in sy besondere gesitueerdheid verstaan word. Thompson ${ }^{35)}$ wys daarop dat bejaardes wat daarop aandring om meer te doen as wat vir hulle goed is, 'n bekende verskynsel is. Die konflik met die siekbed kom hier duidelik na vore. So'n persoon mag vir ' $n$ lang tyd weerstand gebied het teen hospitalisasie of om in die bed te bly. Dit is ' $n$ feit dat immobilisasie, stilstand, bedrus agteruitgang in alle opsigte verhaas. Indien enigsins moontlik behoort hospitalisasie en onnodige bedrus vermy te word en behoort die bejaarde aangemoedig en toegelaat te word om rond te beweeg.

Die ernstig siek bejaarde, soos enige ander sieke wat met die dood konfronteer word, mag weerstand bied teen behandeling - ten volle bewus van die gevolge van sy weiering. Ook en veral hierin wil hy begryp en eerbiedig word.

Weerstand teen siekte, die naderende dood, sou benewens blootstelling aan al die inhoude van hospitalisasie, die pyn en ongemak van fisiese ingrypinge, aantasting van sy menslike waardigheid, selfs chirurgiese ingrepe beteken. Dit sou hom nie toelaat om sy dood tuis in sy vertroude omgewing sinvol af te wag en waardig te sterf nie. Daarom moet die sieke ook met betrekking tot hierdie weiering begryp en eerbiedig word. C.K. Oberholzer sê dat sowel die geneesheer as enige ander (die naasbestaandes. die verpleegkundige) verplig is om so 'n iemand wat bereid is om sy dood te sterf daardie reg en vryheid nie to ontneem nie ${ }^{36)}$.

\section{Die vertrouensverhouding}

Die ontstaan van ' $n$ verhouding van vertroue is afhanklik van die belewing by die bejaarde dat hy as persoon eerbiedig en aanvaar word.

\section{Agting vir die menswaardigheid van die bejaarde sieke}

Die bejaarde neem die agting wat die verpleegkundige en ander lede van die span vir sy waardigheid het waar in die wyse waarop hulle hom as individu, as gespreksgenoot en as lewenspligtige, mede-verantwoordelike mens erken. Ook en veral die bejaarde, wat in sy siekwees onvermydelik van sy verborgene, die intieme dimensies van sy bestaan, aan veel jonger persone moet openbaar, het ' $n$ intense hunkering na die skepping en bewaring van intimiteitsklimaat. Hy het nood aan 'n begrypende, meelewende medemens wat hy kan vertrou en wat hy weet hom sal beskerm teen en in situasies wat sy menswaardigheid bedreig. Die beskikbaarheid van 'n roepstelsel wat hy verstaan en die onmiddellike beskikbaarheid van die verpleegkundige om hom wanner hy deur verleentheid bedreig word tot hul te kom is belangrike faktore in die versterking van vertroue en gedying van geborgenheidsbelewing.

\section{Aanvaarding van die siek bejaarde as persoon}

Hierdie aanvaarding spreek uit die bereidwilligheid van die lede van die terapeutiese span om verhouding met hom te stig, hul gesindhede van liefde en warme medemenslikheid, die opregtheid van hul voorneme om hom te versorg, die feit dat hy waardering vir hom as mens by hulle waarneem, en so meer.

\section{Die gesagsverhouding}

Eerbied vir en aanvaarding van die bejaarde as selfverwerkliker van gesag is van grondliggende belang. Nogtans, juis omdat hy hunker na geborgenheid, is ook die bejaarde sieke gesagsbehoewende wese. Dit gebeur dikwels dat die geneesheer, verpleegkundige of ander lid van die span 'n veel jonger persoon as die pasiënt is. Die opgawe om die sieke te lei tot aanvaarding van die soveel jeugdiger kundige se gesag is dikwels veel groter as in enige ander verhouding met 'n sieke - en verg dikwels baie tyd, geduld en liefde. Dit is egter van deurslaggewende belang indien van die begeleiding van die sieke tot selfstandigheid 'n werklikheid gemaak wil word.

Ook die bejaarde sieke moet aangespreek en opgeroep word tot die aanvaarding van verantwoordelikheid. Dit is soms nodig om sy handelinge, sy gesindheid, af te keur. Wanneer hy misluk, moet verloor, verál dan, het hy nood aan die nabyheid van iemand wat hy weet ook hierdie waarneming van hom in sy swakheid in vertroue sal bewaar. Dit is na sulke momente, vanweë die diepe dankbaarheid van 'n grysaard vir die geborgenheid wat vir hom aan die hand van ' $n$ jong toegewyde medemens moontlik word, dat dit vir hom moontlik en maklik word om sy of haar gesag te gehoorsaam.

Die bejaarde sieke het leiding nodig vir die verwerking van sy situasie. Hy moet leer hoe om homself te versorg. Vanweë fisiese remminge mag dit veel langer neem om 'n handeling te bemeester. Dit is van kardinale belang dat hy genoeg tyd gegun word, aangemoedig word in sy 
pogings. Selfs die geringste vordering moet raakgesien, goedgekeur en aangeprys word. Oorhaastigheid, veeleisendheid is hoogsonwenslik omdat dit die bejaarde terugwerp op die belewing van homself as hulpeloos en dat hy nie begryp, aanvaar of vertrou word nie.

Die opgaaf in die gedying van die gesagsverhouding is die van regverdige, oordeelkundige, liefdevolle en simpatieke gesagsleiding, en erkenning van die bejaarde sieke as gesagsgenoot, as mens met 'n rykdom van ervaring en lewenswysheid. Hy wil geraadpleeg word, hy wil sy mening gee, hy wil in alle beplanning en in elke verkenning van elke situasie deelgenoot wees. Beide die lewensingesteldheid van die professionele persoon en die van die sieke is dus bepalend vir die gedying en bevestiging van hierdie verhouding.

$\mathrm{Na}$ gelang die bejaarde geborgenheid herwin, hom veilig voel in die teenwoordigheid van die lede van die terapeutiese span, groei die bereidheid by hom om betrokke te raak by die terapeutiese gebeure. Dit word vir homself belangrik om weg te breek van sy passiwiteit - hy wil saam-waarneem, saambeplan, saam probleemoplossing van sy situasie doen - hy wil selfs meehelp aan die bedrywighede om 'n ander sieke. 'n Mens staan dikwels verbaas voor die waarneming van 'n feitlik dramatiese veranderde gesindheid by 'n voorheen veeleisende, passiewe bejaarde pasiënt wat by hernuwing van sy oorblywende moontlikhede bewus word.

Deur sy gewaarwording van sy gedyende vermoë tot betekenisvolle dade en dat hy sodanig sonder vrees aan sy eie versorging kan deelneem, sommige fasette daarvan weliswaar op eie verantwoordelikheid kan oorneem, word sy geborgenheidsbelewing versterk, groei daar in hom hernude hoop op die toekoms. Saam met die span kom die bejaarde tot ontwerp van moontlikhede met die oog op herwinning van kragte wat deur die siekte en bedrus verswak is, maar ook met die oog op ontdekking van nuwe belangstellings, sluimerende vaardighede en hier kragtens ontplooiing van nuwe moontlikhede. So word dit vir die bejaarde dikwels moontlik om sy fisiese ontoereikendheid te oorwin en tot sinvolle hervatting van sy lewe in die gemeenskap te kom.

En sou dit nie moontlik wees om die fisiese beperkinge ongedaan te maak nie, dan gedying tot geestelike oorskryding en oorwinning daarvan sodat hy in sy triomferende geestelikheid 'n bron van stille krag en vreugde in die lewens van sy versorgers en naasbestaandes tor die einde sal verteenwoordig.

Hierdie benadering is in totaliteit gerig op die verwerkliking van spesifieke doelstellings. Alle behoeftebepaling, beplanning, hulpverlening en steungewing is daarop gerig dat die bejaarde sieke begelei sal word.

* tot die raaksien en aanvaarding van sy bestaan as geroepenheid en tot vervulling van sin in sy lewe;

* tot toenemende selfbeoordeling en selfbegryping, as realistiese beoordeling en begryping, om so sy waardigheid as mens te behou en inderdaad in die aanvaarding van sy beperkinge tot nuwe waardering van homself te kom;

* tot sedelik-selfstandige besluitvorming en handeling en die aanvaarding van verantwoordelikheid daarvoor;

* tot identifisering met die norme van sy bestaan - as bejaarde, in sy pyn en lyding en in sy toenemende opgaaf met die eindigheid van sy bestaan.

In die geheel gaan dit dus om aktiewe aanvaarding van die bejaarde sieke van die totaal van sy gesitueerdheid. Sy lewensingesteldheid, sowel as die lewensingesteldheid van sy begeleiers is van deurslaggewende betekenis.

Tensy die lede van die terapeutiese span self glo in die sin van die lewe - die van arbeid, pyn en lyding, die dood - en glo in die onherhaalbare, onvervangbare waarde van elke mens se lewe, en tensy hierdie geloof in hul eie lewens, personaal, en in verhouding tot andere, vergestalting kry, kan hulle geen ander mens begelei tot die vervulling van sin in sy eie bestaan nie ${ }^{37}$.

\section{BRONNE}

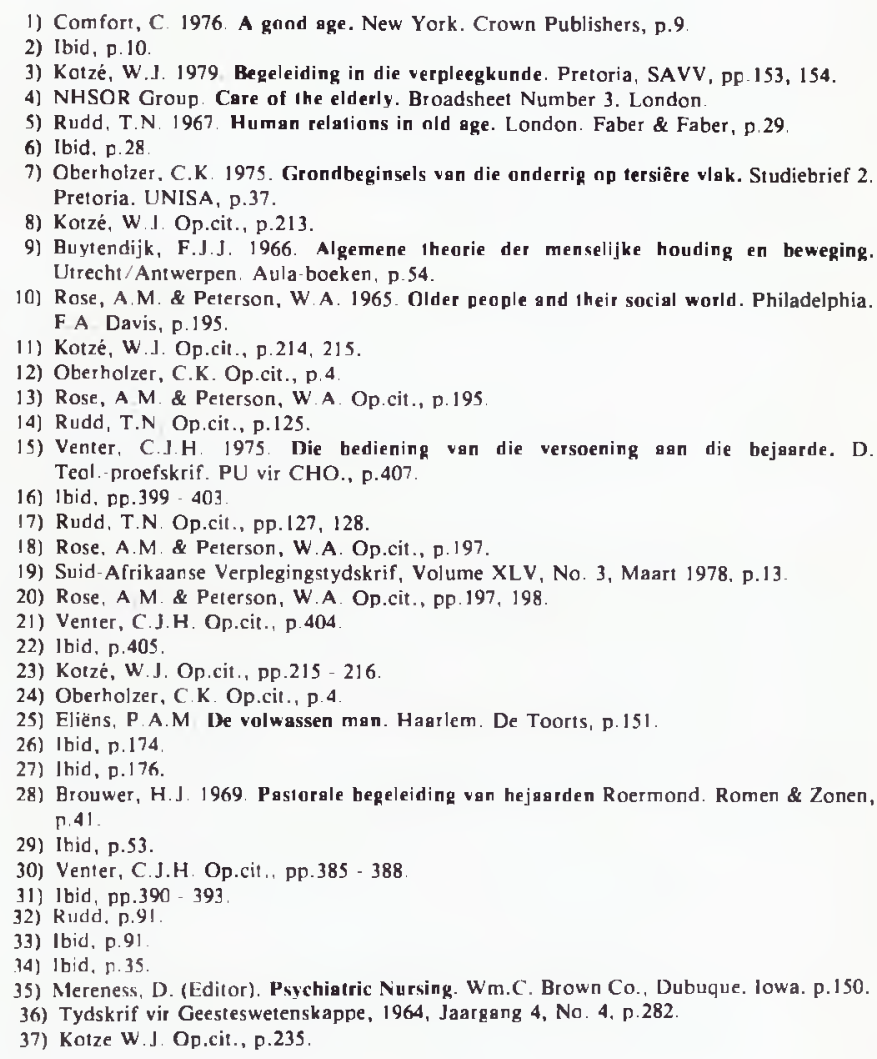

